\title{
Klar - klärer - am klärsten? \\ Umlaut comparison as a doubtful case in contemporary German
}

\author{
Jessica Nowak \\ Johannes Gutenberg University of Mainz \\ nowakj@uni-mainz.de
}

\begin{abstract}
The present paper addresses doubtful cases concerning the use of umlaut in the adjectival comparison of contemporary German: bang 'anxious' - banger/bänger-am bangsten/bängsten. It aims to shed light on the concrete distribution of this variation, i.e. the preference for one of the variants. Corpus-based analyses will show that the adjectives under discussion are not equally affected by umlaut variation: some are (surprisingly) stable (e.g., gesund 'healthy'), whereas many others have a clear preference (i.e. > 70\%) for non-umlauting forms (e.g., blass 'pale', nass 'wet'). Interestingly, a few of the supposedly stable cases appear to have at least some non-umlauting forms (e.g., krank 'ill', $n a h$ 'near', grob 'rough'). Even more interesting (but still comparatively rare) is the use of umlaut in conceptual orality contexts with adjectives that exhibit no umlaut comparison in Standard German, e.g., klar 'clear', falsch 'wrong', doof 'stupid'. As will be demonstrated, these doubtful cases reflect a centuries-old and still ongoing reorganization process within umlaut comparison. It will turn out that a complex network of interacting factors such as token frequency, phonological schemas, and morphological complexity is at work.
\end{abstract}

Keywords: umlaut comparison; adjectives; doubtful cases; German.

\section{Introduction ${ }^{1}$}

Modern (Standard) German is undoubtedly full of grammatical doubtful cases which have attracted not only the interest of amateurs like Bastian Sick (2004) but also that of many professional linguists (e.g., Klein 2003; Thieroff 2009; Nübling 2011). In the past four decades, a wide range of dictionaries have been

\footnotetext{
${ }^{1}$ I would like to thank two anonymous reviewers as well as Stefan Hartmann (Hamburg) for helpful comments on a previous draft of this paper.
} 
published which are exclusively dedicated to linguistic doubtful cases, amongst others the Duden (2011) and Wahrig (2009) dictionaries of doubtful cases. Unfortunately, doubtful cases and variation in language have far too often been interpreted as lack of education and as language decay respectively, especially in the course of late 19th and early 20th century prescriptivism. This paper wants to dispel with this topos by showing that variation results from ongoing language change and that variation is more than natural once language is conceived as a dynamic, self-adaptive system in the sense of Bybee (2010:105).

In order to talk about doubtful cases, it is important to accurately define them first. To this end, we will rely on Klein's (2003:2) definition which sets out four criteria that must be fulfilled by a doubtful case: It is the competent (native) speaker (a) who is thrown into doubt (b) about the correct use as embodied in a Standard language (c) of (at least) two variants $(a, b . .$.$) . The variants of the$ respective linguistic unit (which can be a word, a word form or a sentence) are often partially identical in form (d), compare the Wagen/Wägen 'waggons', Tags/Tages 'of the day', gestaubsaugt/staubgesaugt 'have hoovered'.

The use of umlaut in adjectival comparison meets all four criteria: Comparative and superlative forms with and without umlaut differ from one another only with respect to the feature [+palatal], e.g. karg 'meagre': kärger/karger (am) kärgsten/kargsten. These doubtful cases can be divided into two groups: the first one comprises adjectives like $\mathrm{karg}$ (a) where the historically inherited umlaut is omitted in the comparative and superlative forms, whereas the second group comprises cases like klar 'clear' (b) where umlaut comparison is analogically extended, e.g. klarer $\rightarrow$ klärer, (am) klarsten $\rightarrow$ (am) klärsten (see Section 3.2). However, only adjectives of group (a) are officially documented as doubtful cases in grammars of contemporary German (Eisenberg 2009; Duden 2009) and dictionaries of doubtful cases (Wahrig 2009; Duden 2011), whereas variation resulting from analogical extension of the umlaut principle remains unnoticed. This is particularly interesting because other cases of umlaut extension leading to morphological variation have been extensively discussed in the literature, e.g. the (non-)umlauting plurals of nouns such as (die) Wagen/Wägen '(the) cars', (die) Bogen/Bögen '(the) sheets' etc. (Thieroff 2009). This fact is strongly linked to the question of how prominent doubtful cases are among language users on the one hand and among linguists on the other. This prominence can be measured in terms of frequency distributions, i.e. the extent of the concrete variation in language use, and in terms of metalinguistic discourse, e.g. in online boards. As Nowak (forthc. b) shows, variation in umlaut comparison is hardly discussed in online boards, whereas instances of hypercharacterization in the 
sense of Lehmann (2005) like das einzigste 'the most only' or das optimalste 'the most optimal' generate a lot of attention and controversy among language users. Before elaborating on the concrete corpus-based results in more detail (Section 3.2), it is indispensable to set out a thorough description of adjectival comparison in German (Section 2), i.e. presenting the state of the art and discussing the doubtful cases (2.1) as well as providing a diachronic sketch of umlaut comparison (2.2). It will be demonstrated that the doubtful cases under discussion reflect a centuries-old and still ongoing reorganization process within umlaut comparison that includes a complex network of interacting factors such as token frequency, phonological schemas, and morphological complexity (Section 3).

\section{Adjectival comparison}

\subsection{The state of the art}

While all German adjectives consistently make use of the suffixes -er for the comparative and -sten for the superlative respectively (1a,b), only a few of them additionally exhibit umlaut in Standard German (1b) (e.g. Duden 2009: $\S \S 496 \mathrm{ff}$.).

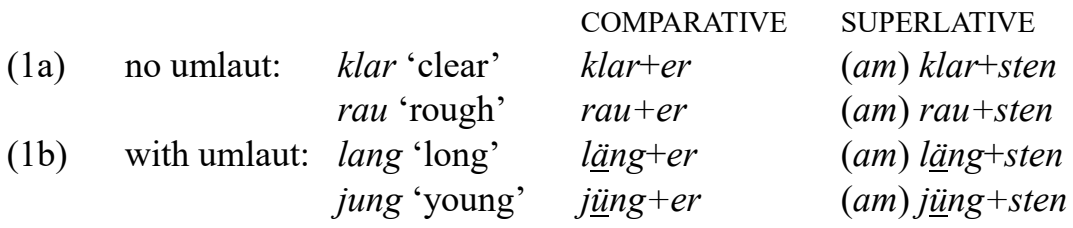

Measured against the total stock of about 250 primary adjectives attested in Lee's (2005) reverse dictionary of Modern German, only 30 adjectives, i.e. $10 \%$, make use of umlaut, see (2): Out of these 30 adjectives, ten are regularly listed as showing variation with respect to umlaut use (2a), whereas the other twenty cases are assumed to exhibit no variation at all (2b).

\section{Umlaut comparison}

(2a) variation: bang, blass, glatt, karg, nass, schmal; fromm, rot; krumm, gesund (disyllabic) 
(2b) no variation: alt, arg, arm, hart, kalt, krank, lang, nah, scharf, schwach, schwarz, stark, warm; grob, groß, hoch; dumm, jung, klug, kurz

However, with the exceptions of fromm 'pious' and rot 'red', which are assumed to show a clear tendency towards umlauting forms (Duden 2009), little to nothing is said in contemporary grammars and dictionaries of doubtful cases about the specific variation, i.e. for example the extent of variation in terms of a preference for non-umlauting over umlauting forms, but also with respect to the individual grammatical categories: Are comparative and superlative forms equally affected by this variation? This question is by no means trivial considering the fact that morphological variation often affects single paradigmatic positions to a different degree, for example in the case of strong versus weak verb forms: Here, preterites are much more prone to variation than their corresponding past participles, compare historically strong verbs like NHG melken 'to milk' or backen 'to bake': melkte/molk, backte (buk) vs. gemolken (gemelkt), gebacken (gebackt) (Dammel et al. 2010). This distribution can be directly linked to frequency effects making the less frequent preterite forms more sensitive to change than the frequently used past participles. Frequency effects will also play a significant role in the doubtful cases under discussion (see Section 3). Moreover, it is important to take other language-external factors like diastratic variation or conceptual orality/literacy in the sense of Koch and Oesterreicher (2007) into account as they may also influence the extent of morphological variation in language use. Finally, we must not lose sight of the several language-internal factors that also have an impact on the preservation of umlaut comparison, such as morphological complexity. Thus, it is said that non-umlauting forms are more often found in compounds of adjectives that have a stable umlaut comparison as simplexes, compare arm 'poor' with blutarm 'exsanguinous' and klug 'smart' with altklug 'precocious': am blutarmsten (but ärmsten), am altklugsten (but klügsten) (Augst 1971:426; Duden 2009).

What is remarkable is the fact that umlaut comparison is not randomly distributed across items but can be reduced to a common denominator of formal features, see the items listed in (2): The first feature is monosyllabicity, which holds for all adjectives exhibiting umlaut (except for gesund 'healthy'). The second feature affects the quality of the stem vowel which is always a monophthong: Most adjectives have $a$ and in some cases $o$ or $u$ in their stems. Thus, polysyllabicity (e.g., mager 'skinny', lustig 'funny') and/or au as a stem vowel (e.g., blau 'blue', genau 'precise') are features excluding umlaut. As we will see in Sections 2 and 3, the synchronic ratio is the result of historical developments 
of umlaut reorganization within adjectival comparison and the phonological schemas that have emerged over time.

\subsection{Umlaut comparison: A diachronic sketch}

Comparative and superlative forms with and without umlaut can be traced back to the earliest stage of the German language, i.e. Old High German ("OHG", c. 750-1050). In this period, there existed two sets of inflectional endings for the comparative/superlative forms: -ôro/-ōsto and -iro/-isto. Only the latter caused umlaut, i.e. a partial regressive assimilation of the stressed vowel (e.g. $a$ ) which took on the palatal quality of the following trigger vowel $i$, compare alt 'old' - eltiro $(<*$ altiro $)$ - eltisto $(<*$ altisto) vs. grōz 'great' - grōzōro grōzōsto. Though the concrete distribution of the two sets of endings has not been satisfactorily addressed yet, there are strong tendencies describing the use of the $\bar{o}$ - and $i$-flexives respectively for OHG: Whereas the -iro/-isto endings almost exclusively combine with monosyllabic primary adjectives, the -ôro/$\bar{o}$ sto endings can also attach to polysyllabic and derived items (e.g. Braune 2004). Hence, polysyllabic adjectives were in principle excluded from umlaut comparison from the very beginning so that the variation between umlauting and non-umlauting comparatives/superlatives was mainly restricted to monosyllabic lexemes, as Figure 1 shows, which sketches the diachrony of umlaut comparison from $\mathrm{OHG}$ to NHG.

Whereas umlaut comparison was originally linked to specific inflectional endings, this predictability was lost on the threshold of the Middle High German ("MHG", c. 1050-1350) period: unstressed full vowels were consequently weakened to schwa, yielding a merger of the different sets of comparative/superlative endings to -er(e)/-est(e). From this time onwards, umlaut comparison was lexicalized and thus idiosyncratic, i.e., the (non-)occurrence of umlaut had to be learnt by rote for each adjective. While polysyllabicity still remained a rather reliable clue for the non-use of umlaut, the variation between umlauting and non-umlauting forms increased in monosyllabic adjectives. Thus, many more cases of formally non-umlauting comparative/superlative forms were attested with umlaut in MHG, although umlaut often remained graphically unmarked for vowels other than $a>e(<e,(, \ddot{a}>)$ until the end of the Early New High German period ("ENHG”). 


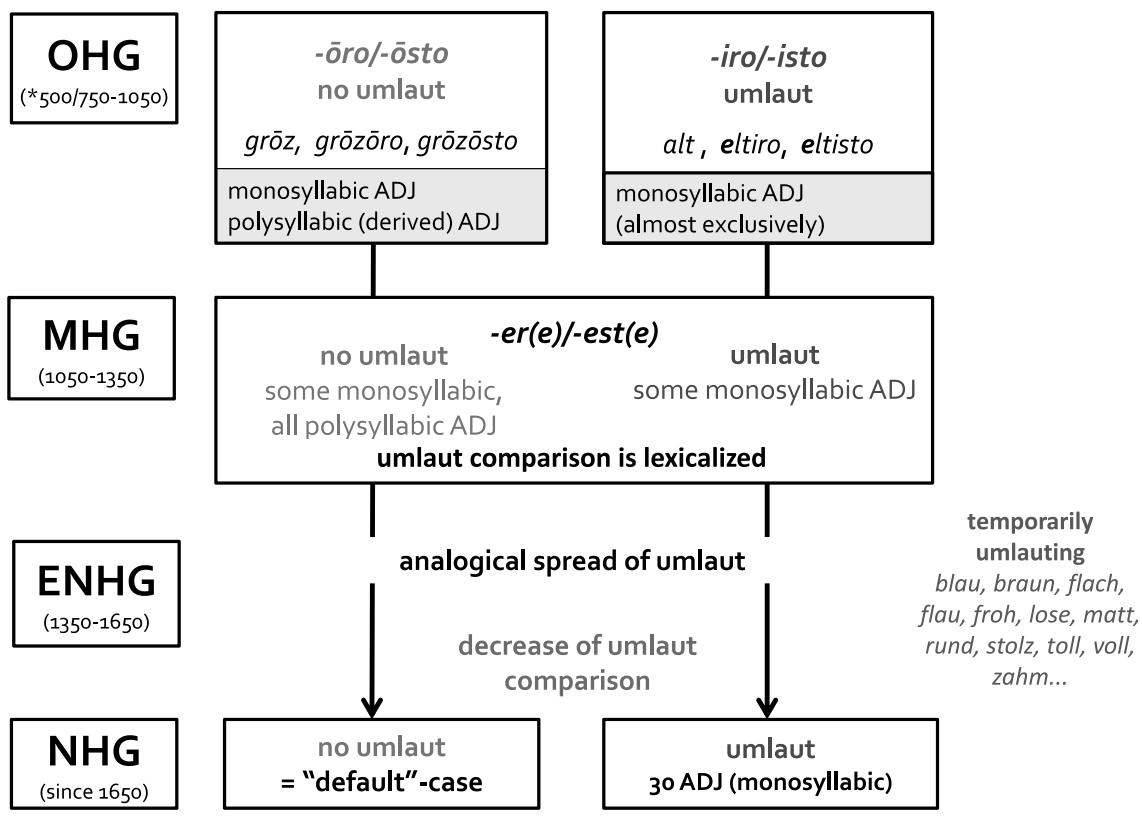

Figure 1. Diachrony of umlaut comparison from Old to New High German.

The ENHG period marks the most important stage of the analogical spread of umlaut as a marker of grammatical categories, not only within adjectival comparison but also in several noun declension classes as a plural marker. Eight adjectives joined umlaut comparison: blass 'pale', fromm 'pious', grob 'coarse/ rude', klug 'smart', krumm 'warped', nass 'wet', rot 'red', and schwach 'weak' (Nowak forthc. a). Interestingly, most of them exhibit umlaut variation to some extent in NHG (see Tables 1 and 2), which leads to the conclusion that umlaut variation may partly reflect a lingering distinction between inherited and analogical umlaut. ${ }^{2}$ Moreover, adjectives like flach 'flat', matt 'dull', zahm 'tame', froh 'happy', lose 'loose', stolz 'proud', toll 'great; crazy, foolish', voll 'full', rund 'round' were temporarily attested with umlaut in their comparative/superlative forms. More interestingly, items containing the diphthong au like blau 'blue', braun 'brown' etc., which are excluded from umlaut compari-

\footnotetext{
${ }^{2}$ I would like to thank an anonymous reviewer for this valuable hint.
} 
son in NHG, were also attested with umlaut in that period. On the basis of several grammars of ENHG, it is possible to calculate a maximum stock of c. 100 adjectives exhibiting umlaut comparison (Nowak forthc. a), see (3) which lists the 55 lexemes temporarily affected by umlaut comparison in ENHG.

Adjectives attested with umlaut comparison in ENHG

a: bald, blank, brav, falsch, flach, (ge)haz, g(e)rad(e), gram, kahl, klar, knapp, la(h)m, laz, matt, rasch, sanft, satt, schlaff, schlank, spat, straff, zahm, zart

o: froh, hohl, hold, los(e), roh, stolz, toll, voll, wohl

u: bunt, plump, rund, strub, stumm, stumpf

au: blau, braun, faul, flau, grau, laut, rau(c)h, schlau

polysyllabic: anmutig, dunkel, genau, hager, lauter, mager, sauber, schade, tapfer

However, it is important to keep in mind that ENHG is far from being a standardized language despite the emerging unification and standardization tendencies at that time. A standard (written) German language did not emerge earlier than the 18th century (Besch 2007). The list in (3) is thus an idealized stock characterized by dialectal traits. Consequently, it is likely that the Upper German dialects which were and still are more susceptible to analogical, i.e. morphological umlaut than the Central German varieties might distort the whole picture (Nübling 2013; Nowak forthc. a).

Nevertheless, the pressing question is how the (massive) decrease of umlaut comparison on the threshold to Modern German can best be accounted for. The stock of umlauting adjectives has been reduced to the thirty items introduced in Section 2.1 (see (2)) so that non-umlauting comparatives/ superlatives mark the "default"-case (see also Figure 1). Moreover, this development also raises the question of why adjectives containing the stem vowel $a u$ did not preserve umlaut, although the alternation pattern $a u-\ddot{a} u$ /av-ol/ is widely attested in nouns (e.g., Haus - Häuser 'house - houses', Raum - Räume 'room - rooms') and verbs (e.g., laufen - läuft 'to walk - (s)he walks'), and also in diminution (e.g., Haufen - Häufchen 'heap - little heap'). It is conceivable that - as Besch (1968) has shown for other domains of the German language - the more regional variants with umlaut comparison have been sorted out in the course of the standardization process. Moreover, the role of grammarians must be clarified in this context, i.e. whether (if at all) and to which extent they exerted an influence on this selection process. Finally, the question has to be raised why analogical umlaut 
(almost) never expanded to polysyllabic items, not even in its "boom" stage in ENHG. These questions will be addressed in the upcoming section.

\section{Determinants in the reorganization of umlaut comparison}

\subsection{The role of token frequency}

It is well-known that language use, i.e. the language users' experience with language, has an impact on the cognitive organization of language, including processing and storage strategies. Bybee (e.g., 2010) identifies three main effects of token frequency on the way items are represented and processed: The first is the Conserving effect which applies to high token frequency items. High frequency of use strengthens memory traces, making items easier to access and also less prone to change in terms of analogical reformation. Thus, irregularity has been maintained in high-frequency strong verbs (e.g., geben - gab 'give - gave'), whereas low-frequency class members have become regularized by joining the productive weak conjugation pattern, compare bellen - boll > bellte 'to bark' (Augst 1975; Nowak 2015; for English see Bybee 2006). High frequency also affects the analysability of morphological complex words in that they are stored and accessed holistically, that is without forming phonological and/or semantic (i.e. functional) connections to other forms of the same paradigm or other word paradigms that would allow the detection of the morphological structure or even of morphological patterns. The second effect is the autonomy of forms resulting from extremely high frequencies, which may lead to lexical splits and the emergence of lexical suppletion, as in the case of verbal paradigms like English gowent, the latter form originally going back to the wend-paradigm (Bybee 1985), or in the comparison of German gern 'gladly' - lieber - am liebsten, formally gerner - am gernsten (Ronneberger-Sibold 1987). The autonomy of forms, in turn, prepares the ground for the third frequency effect: the Reducing Effect. Items that are not decomposed into their individual components are affected by phonetic reduction earlier and at a faster rate than their less frequent counterparts (Bybee 2006, 2010). Building on Werner's $(1987,1989)$ Morphological Economy Theory, Nübling (2000) abandons the idea of conceiving irregularity as morphological junk. Instead, she assigns functionality to inflectional irregularity in high-frequency domains: In this vein, the primary focus of this performance-oriented principle is shortness of expression and low articulatory effort. The increasing shortness, however, bears the risk of syncretisms, as the phonetic 
reductions usually affect "the end or [...] the middle of the word, where most important grammatical categories are marked" (Nübling 2001a: 69). Irregularity, i.e. formal differentiation, in turn, prevents phonetically reduced forms from homophony and can thus be considered highly functional (Nübling 2000: 254 256).

This usage-based theoretical background provides a plausible explanation for two observations concerning umlaut comparison: Firstly, it accounts for the preservation of umlaut in the thirty adjectives of NHG mentioned above, and secondly, it explains why, of these thirty items, only some lexemes are affected by variation. An analysis of Ruoff's (1990: 493) frequency dictionary data of spoken German shows that out of the twenty-five most frequent adjectives with a stem vowel that can be umlauted (i.e. without cases like klein 'small', schön 'beautiful'), sixteen adjectives exhibit obligatory umlaut (4a), three exhibit variation according to grammars (4b), and only six have no umlaut (4c) (Nübling et al. 2013:262):

(4) Correlation of umlaut comparison with token frequency-here: 25 most frequent adjectives according to Ruoff (1990:493)

(4a) obligatory umlaut: alt, arg, arm, dumm, gro $\beta$, hart, hoch, jung, kalt, krank, kurz, lang, nah(e), schwarz, stark, warm

(4b) umlaut variation: gesund, nass, rot

(4c) no umlaut: froh, ganz, rund, tot, voll, wahr

Conversely, this also means that the vast majority of the adjectives with umlaut variation ( 7 out of 10 , see $4 \mathrm{~b}$ ) are not among the more frequent ones. In order to underpin this correlation and to provide a more detailed picture, a frequency analysis was conducted on the basis of the largest corpus of (conceptually) written Modern German, DeReKo (Deutsches Referenzkorpus, Archive W, available via the Cosmas II interface and comprising ca. 8 billion tokens). As the corpus is not tagged for morphological information, the frequency counts are based on the superlative forms only. In contrast to the corresponding non-umlauting comparative forms, which are in many cases homophonous with the inflected attributive forms of the positive degree (see grey cells in 5a), the superlatives are never homophonous with other forms of the same paradigm, even if umlaut is omitted, cf. (5b). 
(5) Homophony in the adjectival paradigm of nass 'wet'.

POSITIVE

nasser [Fuchs]

'wet fox'
COMPARATIVE

no umlaut:

with umlaut: nasser [als]

nässer [als]
SUPERLATIVE

[am] nassesten

[am] nässesten

Figure 2 arranges the different types of umlaut comparison according to their degree of irregularity, i.e. ranging from purely agglutinative structures (e.g., klein 'small' - klein+er - am klein+sten) to modulative ones with varying grades of fusion and culminating in lexical suppletion at the right side of the scale (e.g., gut 'good' - besser 'better' - am besten 'best').

The degree of irregularity strongly correlates with token frequency: Out of the 30 adjectives with umlaut comparison, the ones exhibiting additional changes like suffix allomorphy in the superlative ( $g r o \beta$ 'big' - am größten) or even consonant changes in the comparative (hoch 'high' - höher) or superlative (nah(e) 'near' - am nächsten), have an average frequency of 66 and 147 tokens per million words, whereas their purely umlauting counterparts like alt 'old' exhibit an average frequency of 8 tokens/mio. As predicted by the usage-based account, the ten adjectives with unstable umlaut comparison are of extremely low frequency: they only have an average frequency of less than one token $/ \mathrm{mio}$. Consequently, any inflectional irregularities are eliminated under low and/or decreasing frequencies respectively. Figure 2 also indicates that irregularity and frequency of occurrence negatively correlate with the type frequency of a morphological pattern: The more irregular and idiosyncratic the pattern, the less members it has. Thus, highly suppletive patterns are only found among the three most frequently used items gut 'good', gern 'gladly', and viel 'much', each of them exhibiting an average frequency of 276 tokens/mio. From right to left, the comparison patterns gain in type frequency. On the left-most side of the scale, the productive affix-based pattern is located, comprising the vast majority of German adjectives: In the DeReKo, this pattern is attested for 436 items. In conclusion, the data suggest that frequency of use has been and still is a major determinant with respect to the conservation/elimination of umlaut comparison.

\subsection{The omission of umlaut comparison: corpus-based results}

Let us now turn back to our doubtful cases introduced in Section 1 and first consider the specific degree of variance with respect to umlaut use on the basis of 
Umlaut comparison

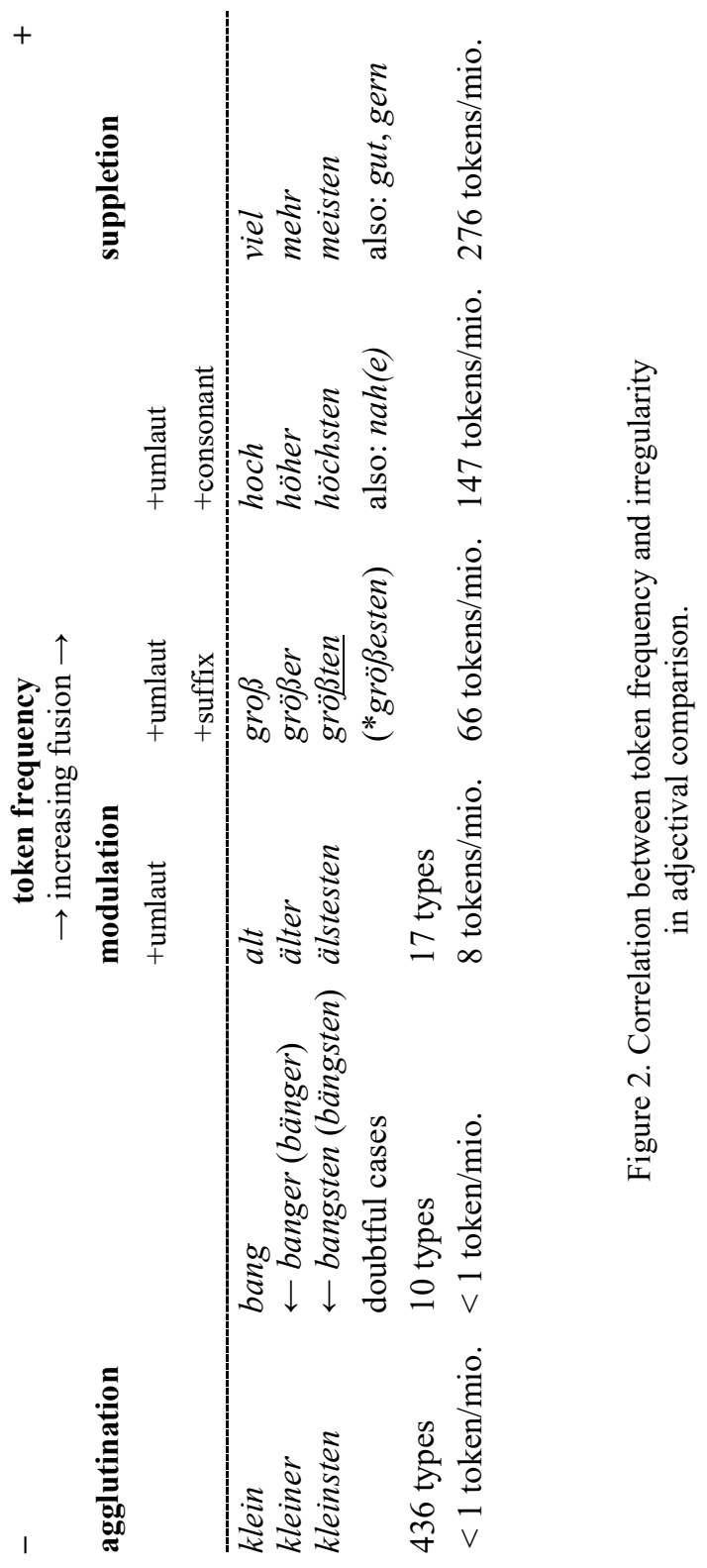


empirical data taken from W-archive of written German in DeReKo. In Tables $1-4$, the results for the comparative refer to the predicative use in combination with als 'than' only (e.g., schmaler/schmäler als), whereas comparatives occurring as attributive adjectives were not included. For the superlative forms, the constructions with $[a m+$ superlative] and [definite article+superlative] were considered, e.g., am schmalsten/schmälsten; der schmalste/schmälste, die schmalsten/ schmälsten etc.

According to the grammars of Modern German and the dictionaries of doubtful cases, the comparatives and superlatives of all ten adjectives should be affected by umlaut omission more or less to the same degree. However, the corpus-based results in Table 1 show a rather different but nevertheless very clear picture: First, with the exception of fromm 'pious', rot 'red', and gesund 'healthy', umlaut comparison practically never occurs, compare blass 'pale' and glatt 'even' on the left-most side, where non-umlauting forms account for more than $95 \%$, or schmal 'narrow' with 79\% non-umlauting comparatives and $98 \%$ non-umlauting superlatives respectively. Second, gesund 'healthy' shows (almost) no variation at all, and can therefore definitely not be considered a doubtful case, see the right-most column in Table 1. Only fromm and rot are affected by variation, whereby forms with umlaut seem not to be clearly favoured in language use as predicted by the grammars. Thus, future editions must be revised to match the synchronic data. The absolute values in Table 1 suggest that frequency is not exclusively responsible for the concrete degree of variation: Items that are less frequent (e.g., fromm, rot) exhibit - at least in some cases - fewer non-umlauting forms than more frequently used ones (e.g., blass, glatt). ${ }^{3}$ As we will see in Section 3.3, this ratio is also determined by phonological schemas.

The results in Table 1 also demonstrate that comparative and superlative forms are equally prone to (non-)variation. Hence, Aldenhoff's (1909) assumption that superlatives favour an umlautless expression is not supported by the data. The omission of umlaut in the comparison degrees was also checked for the twenty adjectives that are not listed as doubtful cases in the grammars (see (2) for the single items). The corpus results generally support the grammars' statements with the exception of grob 'coarse/rude' and krank 'sick', see Table 2 . Both adjectives are slightly affected by variation in the comparative forms

\footnotetext{
${ }^{3}$ As Nübling (2000: 258) points out, the Morphological Economy Theory avoids the naïvemechanistic conception that there is - for instance - a linear correspondence between the absolute token frequencies of a word form and the degree of irregularity preservation (e.g., umlaut comparison). Thus, the comparative of rot exhibits more umlautless forms than the less frequent superlative, see Table 1.
} 
Table 1. Umlautless comparative/superlative forms in the doubtful cases (corpus: DeReKo).

\begin{tabular}{llllllll}
\hline & - & \multicolumn{6}{c}{ umlaut } \\
\cline { 2 - 7 } & blass, glatt & $\begin{array}{l}\text { karg, nass, } \\
\text { krumm }\end{array}$ & schmal & bang & fromm & rot & gesund \\
\hline COMP & $\begin{array}{l}\text { 95\% } \\
(\mathrm{n}=276+120)\end{array}$ & $\begin{array}{l}>95 \% \\
(\mathrm{n}=36+69+17)\end{array}$ & $\begin{array}{l}79 \% \\
(\mathrm{n}=1,084)\end{array}$ & $\begin{array}{l}(\mathrm{n}=3) \\
\text { SUP }\end{array}$ & $\begin{array}{l}66 \% \\
(\mathrm{n}=58)\end{array}$ & $\begin{array}{l}47 \% \\
(\mathrm{n}=103)\end{array}$ & $\begin{array}{l}1 \% \\
(\mathrm{n}=1,606)\end{array}$ \\
\hline
\end{tabular}

(12\% with no umlaut each). In the superlative forms, however, only krank exhibits variation but to a greater extent (23\%). Interestingly, krank is far less often used in the superlative $(n=102)$ than in the comparative degree $(n=261)$, which might explain the varying degrees of umlaut variation, i.e. the higher frequency of use stabilizes umlaut and vice versa. Token frequency also explains the fact that the umlaut use in the superlative of grob is stable: It is much more often used $(\mathrm{n}=5,011)$ than the corresponding comparative forms.

Table 2. Umlautless comparative and superlative forms for grob and krank.

\begin{tabular}{lclcc}
\hline & predicative comparative & \multicolumn{2}{c}{ am-superlative } \\
\hline grob & $12 \%$ & $(\mathrm{n}=106)$ & UL stable $(\mathrm{n}=5,011)$ \\
krank & $12 \%$ & $(\mathrm{n}=261)$ & $23 \%$ & $(\mathrm{n}=102)$ \\
\hline
\end{tabular}

A third query was conducted to check the Duden grammar's assumption that umlaut is more often omitted in compound adjectives such as blutarm 'exsanguinous' than in their corresponding bases. Here, all thirty adjectives exhibiting umlaut comparison in Standard Modern German were included. As the results listed in Table 3 show, only a few of them confirm the correlation between morphological complexity and umlaut omission: These are karg 'meagre', gesund 'healthy', klug 'smart', nah(e) 'near', arm 'poor', and hart 'hard'.

Interestingly, comparative and superlative forms behave inconsistently with respect to umlaut omission across compound adjectives and within the same adjectival base. Thus, in the case of gesund, which seldom exhibits in- 
Table 3. Umlautless comparative and superlative forms depending on morphological complexity.

\begin{tabular}{llcrrr}
\hline & & \multicolumn{2}{c}{$\mathrm{C}$} & & \multicolumn{2}{c}{$\mathrm{S}$} \\
\hline \multirow{2}{*}{ karg } & simplex & $100 \%$ & $\mathrm{n}=36$ & $83 \%$ & $\mathrm{n}=48$ \\
& compound & $100 \%$ & $\mathrm{n}=25$ & $100 \%$ & $\mathrm{n}=12$ \\
\hline \multirow{2}{*}{ gesund } & simplex & $1 \%$ & $\mathrm{n}=1,606$ & $2 \%$ & $\mathrm{n}=1,500$ \\
& compound & $8 \%$ & $\mathrm{n}=118$ & $22 \%$ & $\mathrm{n}=82$ \\
\hline \multirow{2}{*}{ klug } & simplex & --- & $\mathrm{n}=1,566$ & ---- & $\mathrm{n}=2,318$ \\
& compound & $17 \%$ & $\mathrm{n}=17$ & --- & $\mathrm{n}=28$ \\
\hline \multirow{2}{*}{ nah } & simplex & --- & $\mathrm{n}=18,762$ & --- & $\mathrm{n}=1,358,462$ \\
& compound & $17 \%$ & $\mathrm{n}=335$ & --- & $\mathrm{n}=24,237$ \\
\hline \multirow{2}{*}{ arm } & simplex & --- & $\mathrm{n}=560$ & --- & $\mathrm{n}=17,328$ \\
& compound & $3 \%$ & $\mathrm{n}=368$ & --- & $\mathrm{n}=1,449$ \\
\hline \multirow{2}{*}{ hart } & simplex & --- & $\mathrm{n}=4,284$ & --- & $\mathrm{n}=17,839$ \\
& compound & --- & $\mathrm{n}=16$ & $3 \%$ & $\mathrm{n}=137$ \\
\hline
\end{tabular}

stances without umlaut, non-umlauting forms are much more often found in the superlative than in the comparative form ( $22 \%$ vs. $8 \%)$. In the -hart compounds, it is the superlative that is exclusively affected by umlaut omission, whereas in the -klug, -nah(e), and -arm compounds, this holds only for the comparatives, compare Table 3. It can be assumed that token frequency is responsible for this distribution as the compounds under discussion are of lower frequency than their corresponding bases, compare, for instance, gesund with 1,606 hits in the comparative and 1,500 hits in the superlative but only 118 hits and 82 hits as a compound. Moreover, the lexicalisation degree of the compounds may also play a role, compare, e.g. blutarm 'exsanguinous', whose base is probably at best weakly associated with the meaning of the simplex 'poor (with respect to material goods)', and thus no longer inflected like arm, but according to the productive non-umlauting comparison pattern. Another factor that potentially interacts with token frequency is polysyllabicity. As outlined in the diachronic sketch in Section 2.2, umlaut comparison is restricted to monosyllabic lexemes in NHG. All compounds are at least disyllabic, in many cases they even exceed two syllables, e.g., kalorienarm 'low in calories' with five syllables. Hence, though 
containing an adjectival base that involves umlaut in the gradation degrees, they do not match the prototypical disyllabic structure of umlauted comparatives and superlatives as represented by ärmer, ärmsten, and trisyllabic in the superlatives of lexemes ending in $-t /-d$, compare härtesten (see also 3.2). The disyllabic structure of inflected forms with umlaut as grammatical marker is also found in the plural of nouns (6a) and the subjunctive of irregular ${ }^{4}$ verbs (6b) as well as in derivation, compare the -in-derived feminine nouns in (6c) and the diminutives in (6d).

$\begin{array}{llll}\text { nouns: } & \begin{array}{l}\text { Apfel } \\ \text { Grund }\end{array} & \begin{array}{l}\text { Äpfel } \\ \text { Gründe }\end{array} & \begin{array}{l}\text { 'apples' } \\ \text { 'reasons' } \\ \end{array} \\ \text { Lamm } & \begin{array}{l}\text { Lämmer } \\ \text { 'lambs' }\end{array} \\ \text { verbs: } & \text { sang } & \text { sänge } & \text { 'would sing' } \\ & \text { hatte } & \text { hätte } & \text { 'would have' } \\ & \text { war } & \text { ware } & \text { 'would be' } \\ \text {-in-suffix } & \text { Papst } & \text { Päpstin } & \text { 'pope (fem.)' } \\ \text { diminutive } & \text { Katze } & \text { Kätzchen } & \text { 'little cat, kitten' }\end{array}$

The fact that umlaut use in general and umlaut comparison in particular clearly favour trochaic disyllabic structures leads us to the next factor determining the conservation, omission and extension of umlaut comparison in NHG discussed in the following Section.

\subsection{Phonological schemas}

As already mentioned in Section 1, the NHG adjectives with umlaut comparison have many phonological features in common, e.g. monosyllabicity and the monophthongal stem vowel. This allows us to arrange the items according to these two features. In addition, we can detect additional shared properties such as word initial and/or final consonant clusters, compare Figure 3 (the "official" doubtful cases are printed in bold type, the variation in grob and krank is indicated by the curved lines).

\footnotetext{
${ }^{4}$ Here, the term is used to comprise all verbs that deviate from the regular weak paradigm, i.e. strong verbs (e.g., singen) as well as verbs of different suppletion degrees (haben, sein).
} 


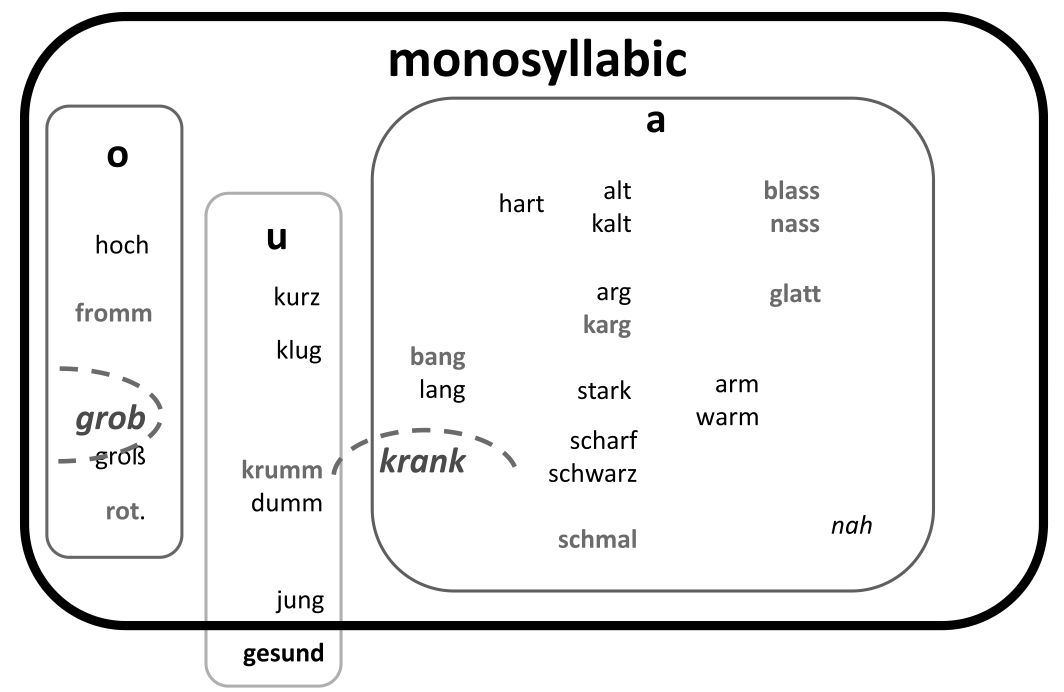

Figure 3. Shared phonological properties across adjectives with umlaut comparison in NHG.

The single items represent instantiations of the most specific schema of adjectives exhibiting umlaut comparison in the sense of Bybee (e.g., 1985, 1988). Each type forms phonological connections with other items along shared features, ranging from identity match as in case of rhyming pairs like alt 'old' and kalt 'cold' (solid line) to partial matches as in the case of these two adjectives with hart 'hard' (broken line), as they exhibit a final consonant cluster sonorant $+t$, compare Figure 4 on the left.
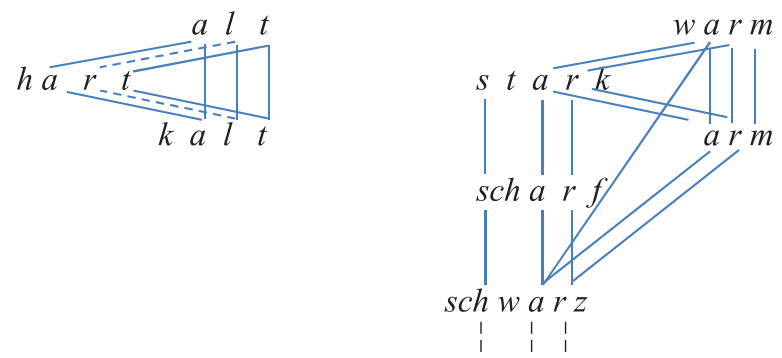

abstract schema $[(\mathrm{C})(\mathrm{C})$ a $\mathrm{SC}]$

Figure 4. Emergence of phonological schemas among adjectives. 
The common properties result in generalizations across items and thus in more general, i.e. more abstract schemas such as $[(\mathrm{C})(\mathrm{C}) \mathrm{aSC}]$ which also comprises arg 'bad', karg 'meagre', stark 'strong', scharf 'sharp; spicy', schwarz 'black', arm 'poor', and warm 'warm', compare Figure 4 on the right (for better readability not all connections between shared features are considered here). The quantitative distribution of shared features allows us to classify/identify the $[(\mathrm{C})(\mathrm{C}) \mathrm{aSC}]$ schema as the phonological prototype of an NHG adjective with umlaut comparison.

An adjective like kurz thus differs in the stem vowel from the schema depicted in Figure 4 above but shares its consonant structure. According to Bybee (e.g. 1988), the more types a schema comprises, the more stable it is. Hence, items that belong to a type-frequent schema are less prone to regularizing analogical change. This holds especially for low-frequency cases, where typefrequency is the only stabilizing factor. If we take a closer look at Figure 3, where the doubtful cases under discussion are highlighted in bold characters, the stabilizing effect of type-frequency becomes evident. The adjectives affected by umlaut variation are those that belong to the less type-frequent schemas, i.e. those with a stem vowel other than $a$, and/or those that have the least shared properties with the prototype $[(\mathrm{C})(\mathrm{C}) \mathrm{aSC}]$; compare, for instance, bang 'anxious', schmal 'narrow', glatt 'even', blass 'pale', nass 'wet', rot 'red', krumm 'warped'. In formally isolated items like hoch 'high', gesund 'healthy' or nah(e) 'near' it is thus their higher frequency of use that guarantees the preservation of umlaut comparison.

Besides the stabilizing, i.e. conserving effect of type-frequency, typefrequency also influences the productivity of a schema. Hence, the representation of a schema with many members is cognitively reinforced and more likely to attract new items that fit into the schema (see Bybee 1988). A prime example for this is the string/strung-class in English, which attracted new verbs - strong and weak ones - over the course of time (Bybee and Moder 1983). Interestingly, this schema is product-oriented rather than source-oriented, which means that generalizations across items emerge among the derived inflected preterite forms and thus describe the output of the preterite. Thus, new members need not necessarily match the phonological form of the source, i.e. the infinitive, to join the string/strung-class, compare hang which does not share the stem vowel [I]. In this case, it is not the basic-derived relation "change infinitival [I] to preterital $[\Lambda]$ " that is analogically extended. Product-oriented schemas are rather common across strong verbs because the vowel changes are historically based on ablaut, where the relationship between the vowel of the base and the vowel(s) of its de- 
rived forms has become idiosyncratic. Hence, a vowel in the infinitive corresponds to a qualitatively different vowel in the preterite and past participle respectively, compare sing-sang-sung or drive-drove-driven (for German see Nowak 2015). In contrast, the umlaut relationship is still transparent - at least in German $^{5}$ - and can be described in terms of palatalization: $a$ always corresponds to $\ddot{a}$, $o$ to $\ddot{o}$, and so on (see Nübling 2001b; Nübling and Dammel 2004). Consequently, we can/may assume that an analogical extension of umlaut comparison to new adjectives in Modern German is best described in terms of a source-oriented generalization.

Taking this as a starting point, we can derive two main hypotheses regarding the analogical extension of umlaut comparison in NHG: First, monosyllabic adjectives are more likely to exhibit non-standard comparative/superlative forms with umlaut. More specifically, items matching the prototype $[(\mathrm{C})(\mathrm{C}) \mathrm{aSC}]$ of adjectives with umlaut comparison described above will be more prone to adopt umlaut. Second, it is expected that lexemes with the diphthong au (e.g., braun 'brown') will not be attracted at all. To test these hypotheses a corpus analysis was conducted with Cosmas II. The results which are arranged according to the stem vowel are given in Table 4 (the items which are frequently attested with umlaut comparison are highlighted in boldface).

Table 4. Adjectives with non-standard umlaut comparison in the DeReKo.

\begin{tabular}{llcc}
\hline $\begin{array}{l}\text { stem } \\
\text { vowel }\end{array}$ & $\begin{array}{l}\text { adjectives with non-standard umlaut forms } \\
\text { a }\end{array}$ & $\begin{array}{l}\text { brav, falsch, flach, harsch, klar, knapp, krass, } \\
\text { mager, schlank, schlank, schlapp, zahm, zart }\end{array}$ & $\begin{array}{c}\text { adjectives with } \\
\text { standard umlaut forms }\end{array}$ \\
& $\begin{array}{l}\text { braun, genau, grau, lau, laut, sauber, sauer, } \\
\text { au }\end{array}$ & 8 & 19 \\
o & $\begin{array}{l}\text { schlau } \\
\text { doof, forsch, stolz, toll, tot, voll }\end{array}$ & 6 & - \\
$\mathrm{u}$ & dunkel, rund, stumpf & 3 & 6 \\
\hline
\end{tabular}

The first hypothesis is supported by the observation that adjectives with $a$ are much more often (12 items) attracted by umlaut comparison than those with $o$

\footnotetext{
${ }^{5}$ Compare, however, the English cases of umlaut like old-elder or foot-feet, which are synchronically idiosyncratic (for Luxembourgish see Nübling 2001b).
} 
and $u$ as a stem vowel (6 and 3 items respectively). However, only a few of them have concrete rhyme-partners in Standard German that might serve as an analogical model: krass 'stark' has blass 'pale' and nass 'wet', schlank 'slim' has krank 'sick', zart 'delicate' has hart 'hard', and rund 'round' has gesund 'healthy'. Falsch 'wrong', harsch 'harsh', and zart 'delicate' are the only ones that match the prototype $[(\mathrm{C})(\mathrm{C}) \mathrm{aSC}]$. Table 4 also displays some unexpected results: First, adjectives with $a u$ are relatively often attested with umlaut comparison (8 items), disproving the second hypothesis. Second, we also find five cases of disyllabic items that exhibit umlaut, e.g., mager 'skinny', sauber 'clean', and dunkel 'dark'. However, most of the latter undergo syncope of $e$ at least in the comparative forms, thus remaining disyllabic, compare mäg(e)rer, säu(e)rer, dünk(e)ler with kälter, gröber, jünger.

The fact that phonological schemas alone do not explain the analogical behaviour of umlaut comparison needs further explanation. It is conceivable that factors like the dialectal background of the language users also have an impact on the use of analogical umlaut. As briefly hinted at in Section 2.2, morphological umlaut is much more widespread in South-West German dialects (Nübling 2013). In Swiss German, for instance, umlaut comparison is attested for c. 60 adjectives, including disyllabic ones as well as items with au (Nowak forthc. a). It might therefore be assumed that dialectal transference is at work here, as it is the case for umlaut plurals like Wägen 'cars', Bögen 'curves, arcs', Köffer 'suitcases'. But this assumption needs further empirical testing. Analogical umlaut use might also be influenced by derivationally related items exhibiting umlaut, compare, e.g., Bräune 'tan' and bräunen 'to brown', säubern 'to clean'. 6

A closer look at the specific contexts in which analogical umlaut comparison is attested in the DeReKo corpus data reveals that many of these adjectives are used in frames of the type $[X$-er als $X]$ 'more $\mathrm{X}$ than $\mathrm{X}$ ', e.g., töter als tot 'more dead than dead' or fälscher als falsch 'more wrong than wrong', and the frame [X und X-er] 'X and more X', e.g., klar und klärer 'clear and clearer', rund und ründer 'round and rounder', schlapp und schläpper 'weak and weaker', stumpf und stümpfer 'blunt and blunter'. 7 The latter frame may have a concrete analogical model in noch und nöcher 'more and more, again and again', which is relatively frequently used in Modern German (451 hits in DeReKo).

\footnotetext{
${ }^{6}$ I would like to thank an anonymous reviewer for this valuable hint.

${ }^{7}$ As an anonymous reviewer pointed out, this frame is also found in the title of the movie Dumb and Dumber (German Dumm und Dümmer), exhibiting hypercharacterization in the sequel to this movie, namely Dumb and Dumberer (German Dumm und Dümmerer), see also example (7b).
} 
Thus, it is not only the phonological schema that determines the analogical spread of umlaut comparison but also the wider context in which the adjective is used. Many of these analogical umlaut uses are found in jocular language, a context in which ablaut pattern extensions have also been attested, for example for Dutch (Knooihuizen and Strik 2014), and German (Nowak 2015). A good example of this is the record Rudi hat die Nase völler, in which the surname of the formal football player Rudi Völler which is homophonous with the umlauted comparative of voll 'full' is used as an adjective in the phraseological context die Nase voll haben 'to be fed up with' (lit. 'to have a full nose'). This jocular use is also found in catchy slogans, which make use of non-standard regularized (gerner instead of lieber, (7a)) or hypercharacterized comparative forms (netterer instead of netter, (7b)) for the sake of rhyme only, compare:

(7a) Zu Werner geh'ich gerner. 'I prefer to go to [the bakery] Werner.'

(7b) Ketterer sind netterer. 'Ketterer [a beer label] are more friendly (lit. more friendlier).'

\section{Conclusion}

Grammatical variation causing phases of uncertainty (i.e. doubtful cases) among language users is symptomatic for ongoing language change. The present paper has dealt with umlaut variation in NHG adjectival comparison from a functional perspective, relying on diachronic and synchronic quantitative data, in order to examine the guidelines by which umlaut comparison is omitted, preserved or even analogically extended in language use.

It has been shown that umlaut variation affecting monosyllabic adjectives is historically inherited from OHG. However, the key determinant influencing the preservation of umlaut comparison in NHG is token frequency: Whereas many more adjectives once exhibited umlaut in their comparative/superlative forms especially in Early New High German (ENHG, 1350-1650) - only the most frequent ones have conserved it until the present day (e.g., alt 'old', gro $\beta$ 'great', jung 'young'). Consequently, umlaut variation in NHG only affects lowfrequency items. However, as the corpus results have shown, most doubtful cases exhibit (almost) no variation at all, as umlaut comparison has been completely abolished here (e.g., blass 'pale', glatt 'even'). Phonological schemas across adjectives with umlaut comparison have also been detected to co-influence the stability of umlaut use: Items that do not share enough features with the proto- 
type are more likely to join the type-frequent umlautless comparison pattern. This also explains why some of the supposedly stable cases of umlaut comparison like grob 'coarse/rude' and krank 'sick', which are peripheral members of the detected phonological schema, show at least some variation in the data. Phonological schemas also explain the analogical extension of umlaut comparison attested - at least to some extent - in written language. However, the analogical umlaut use is also may also be motivated by jocular language and dialectal transference. Last but not least, morphological complexity, which correlates with the umlaut-excluding feature of polysyllabicity, has some impact on umlaut omission, thus dispreferring umlaut comparison in compounds compared to their simplex bases.

\section{References}

Aldenhoff, J. 1966. "Der Umlaut in deutschen Komparationsformen". Revue des langues vivantes 32. 468-492.

Augst, G. 1971. "Über den Umlaut bei der Steigerung”. Wirkendes Wort 21. 424-430.

Besch, W. 1968. "Zur Entstehung der neuhochdeutschen Schriftsprache”. Zeitschrift für deutsche Philologie 87. 405-426.

Besch, W. 2007. “,Vertikalisierung' und ,Leitvarietät'. Terminologie-Probleme im Blick auf die Entstehung der neuhochdeutschen Schriftsprache”. Zeitschrift für deutsche Philologie 126. 411-419.

Bybee, J. L. 1985. Morphology. A study of the relation between meaning and form. Amsterdam: John Benjamins.

Bybee, J.L. 1988. "Morphology as lexical organization". In: Hammond, M. and M. Noonan (eds.): Theoretical morphology. Approaches in modern linguistics. San Diego: Academic Press. 119-141.

Bybee, J.L. 2006. From usage to grammar: The mind's response to repetition. Language 82:4. 529-551.

Bybee, J.L. 2010. Language, Usage and Cognition. Cambridge: Cambridge University Press.

Bybee, J.L. and C.L. Moder. 1983. "Morphological classes as natural categories". Language 59(1). 251-270.

Bybee, J.L. and J.L. McCelland. 2005. "Alternatives to the combinatorial paradigm of linguistic theory based on domain general principles of human cognition". The Linguistic Review 22. 381-410.

Braune, W. and I. Reiffenstein. 2004. Althochdeutsche Grammatik I. Laut- und Formenlehre. Tübingen: Niemeyer.

Dammel, A. et al. 2010. "Strong verb paradigm levelling in four Germanic languages. A category frequency approach". In: Hüning, M. et al. (eds.): Journal of Germanic linguistics 22.4-Special issue on comparative linguistics: Dutch between English and German. 337-359. 
Duden. 2009. Die Grammatik (Duden Band 4). Mannheim: Dudenverlag.

Duden. 2011. Richtiges und gutes Deutsch (Duden Band 9). Mannheim: Dudenverlag. Knoohuizen, R. and O. Strik. 2014. "Relative productivity potentials of Dutch verbal inflection patterns". Folia Linguistica Historica 35(1). 173-200.

Koch, P. and W. Oesterreicher. 2007. "Schriftlichkeit und kommunikative Distanz". Zeitschrift für germanistische Linguistik 35. 346-375.

Lee, D.H. 2005. Rückläufiges Wörterbuch der deutschen Sprache. Berlin: De Gruyter.

Lehmann, C. 2005. "Pleonasm and hypercharacterisation". Yearbook of Morphology 2005. $119-154$.

Nowak, J. 2015. Zur Legitimation einer 8. Ablautreihe. Eine kontrastive Analyse zur ihrer Entstehung im Deutschen, Niederländischen und Luxemburgischen. Hildesheim: Olms.

Nowak forthc. a. "Falsch-fälscher-Steigerungsumlaut? Zur Reorganisation des Umlauts in der deutschen Adjektivsteigerung".

Nowak forthc. b. "Fälscher als falsch? Der Steigerungsumlaut als grammatischer Zweifelsfall” [working title]. In: Szczepaniak, R. et al. (eds.), Doubtful cases: A fresh look.

Nübling, D. 2000. Prinzipien der Irregularisierung. Eine kontrastive Analyse von zehn Verben in zehn germanischen Sprachen. Tübingen: Niemeyer.

Nübling, D. 2001a. "The development of 'junk'. Irregularization strategies of HAVE and SAY in the Germanic languages". In: Booij, G. and J. van Marle (eds.), Yearbook of Morphology 1999. Dordrecht: Kluwe. 53-74.

Nübling, D. 2001b. "Wechselflexion Luxemburgisch - Deutsch kontrastiv: ech soen du sees/si seet vs. ich sage, du sagst, sie sagt. Zum sekundären Ausbau eines präsentischen Wurzelvokalwechsels im Luxemburgischen”. Sprachwissenschaft 26(4). 433-472.

Nübling, D. 2011. “Unter großem persönlichem oder persönlichen Einsatz? Der sprachliche Zweifelsfall adjektivischer Parallel- vs. Wechselflexion als Beispiel für aktuellen grammatischen Wandel”. In: Köpcke, K.-M. and A. Ziegler (eds.): GrammatikLehren, Lernen, Verstehen. Zugänge zur Grammatik des Gegenwartsdeutschen. Reihe Germanistische Linguistik. Berlin: De Gruyter.175-195.

Nübling, D. 2013. “Zwischen Konservierung, Eliminierung und Funktionalisierung: Der Umlaut in den germanischen Sprachen”. In: Fleischer, J. and H. Simon (eds.), Comparing Diachronies. Berlin: De Gruyter. 15-42.

Nübling, D. and A. Dammel. 2004. "Relevanzgesteuerter morphologischer Umbau im Frühneuhochdeutschen". $P B B$ 126. 177-207.

Nübling, D. et al. 2013. Historische Sprachwissenschaft des Deutschen. Eine Einführung in die Prinzipien des Sprachwandels. Tübingen: Narr.

Paul, H. 2007. Mittelhochdeutsche Grammatik. Neu bearbeitet von Thomas Klein, HansJoachim Solms \& Klaus-Peter Wegera. Mit einer Syntax von Ingeborg Schrobler, neubearbeitet und erweitert von Heinz-Peter Prell. Tübingen: Niemeyer.

Ronneberger-Sibold, E. 1987. "Verschiedene Wege zur Entstehung von suppletiven Flexionsparadigmen: Deutsch gern - lieber-am liebsten ". In: Boretzky, N. et al. (eds.), Beiträge zum 3. Essener Kolloquium über Sprachwandel und seine bestimmenden Faktoren. Bochum: Brockmeyer. 243-264.

Sick, B. 2004. Der Dativ ist dem Genitiv sein Tod. Köln: KiWi. 
Solms, H.-J. et al. 1991. Grammatik des Frühneuhochdeutschen. Band 6: Flexion der Adjektive. Heidelberg: Winter.

Thieroff, R. 2009. "Über den Pluralumlaut beim Substantiv". In: Eins, W. and F. Schmöe (eds.), Wie wir sprechen und schreiben. Wiesbaden: Harrassowitz. 27-43.

Wahrig. 2009. Fehlerfreies und gutes Deutsch (Band 5). Gütersloh/München: Wissensmedia.

Werner, O. 1987. "The aim of morphological change is a good mixture - not a uniform language type". In: Ramat, G.A. et al. (eds.), Papers from the 7th international Conference of Historical Linguistics, Amsterdam. 591-616.

Werner, O. 1989. "Sprachökonomie und Natürlichkeit im Bereich der Morphologie". Zeitschrift für Phonetik, Sprachwissenschaft und Kommunikationsforschung 42. 34 47.

Address for correspondence:

Jessica Nowak

German Department

Johannes Gutenberg University of Mainz

Jakob-Welder-Weg 18

D-55128 Mainz

Germany

nowakj@uni-mainz.de 